\title{
Responsible unionism during collective bargaining and industrial action: Are we ready yet?
}

Monray Marsellus Botha*

BLC, LLB, LLM, BCom (Hons) (UP), MCom (UJ), LLD (NWU)

Senior lecturer in Mercantile Law, Faculty of Law, North-West University

(Potchefstroom Campus)

\section{OPSOMMING}

Verantwoordelike Vakbond Optrede Gedurende Kollektiewe Bedinging en Nywerheidsaksie: Is ons Gereed?

\begin{abstract}
Vakbonde speel nie net 'n belangrike rol in die kollektiewe bedingingsproses (ingesluit nywerheidsaksie) nie maar ook in die breër ekonomie en samelewing. Daar word dus verwag van vakbonde om nie net verantwoordelik op te tree wanneer hulle beding namens hulle lede nie maar ook as verantwoordelike burgers in die algemeen op te tree. Hierdie verantwoordelikheid word verder uitgebrei wanneer vakbonde in die publiek wil protesteer en moet hulle dus verantwoordelikheid neem vir hul lede se optrede in die openbaar. In hierdie artikel word ondersoek ingestel na die vraag of vakbonde verantwoordelik gehou moet word vir die optrede van hul lede wat skade aan ander se eiendom veroorsaak sowel as of vakbonde anders moet optree wanneer hulle met werkgewers beding vir die verbetering van werknemers se lone en diensvoorwaardes.
\end{abstract}

\section{Introduction}

In 1995 the South African labour market was transformed by the introduction of the Labour Relations Act (the "LRA"). " The LRA is the primary piece of labour legislation that governs labour law in South Africa. It marks "a major change in South Africa's statutory industrial relations system" and, following the transition to political democracy, the LRA encapsulates the government's aims to reconstruct and democratise the economy and society in the labour relations arena. ${ }^{2}$ Other important pieces of labour legislation in South Africa are the Basic Conditions of Employment Act (the "BCEA") ${ }^{3}$ and the Employment Equity Act (the "EEA"). ${ }^{4}$ The notion of industrial democracy and transformation of the workplace are central issues in South African labour law. Constitutional change in South Africa has advanced the protection of human rights and the democratisation of the workplace.

\footnotetext{
E-mail monray.botha@nwu.ac.za

1 Act 66 of 1995.

2 Du Toit et al Labour Relations Law (2006) 5

3 Act 75 of 1997.

4 Act 55 of 1998 .
}

How to cite: Botha 'Responsible unionism during collective bargaining and industrial action: Are we ready yet? 
Trade unions in South Africa, even prior to 1994, demand greater democracy in the workplace: Some employers have taken initiatives to involve employees in decision-making. ${ }^{5}$ Rights, such as the freedom of association, as well as the rights to organise and strike are afforded to employees and recognised by both the Constitution of the Republic of South Africa, $1996^{6}$ and the LRA. ${ }^{7}$ Other rights, such as freedom of trade, occupation and profession, are also provided for in the Constitution. ${ }^{8}$ The constitutional right of "[e]very trade union, employer's organisation and employer" to "engage in collective bargaining" is also provided for. ${ }^{9}$

The Constitution grants every person a fundamental right to fair labour practices and the right of workers to strike. ${ }^{10}$ The right to strike as well as the right to engage in collective bargaining is regulated by the LRA. ${ }^{11}$ Trade unions occupy a particular place in the South African labour market as well as in the economy: They affect the functioning of a business, organisation or workplace internally or externally. Collective bargaining (coupled with the right to strike) has become a primary means to force employers to negotiate on the improvement of standards and conditions of employment.

In the context of the rights and freedoms granted to trade unions, the author attempts to address the issue regarding "responsible unionism". The article, however, will not discuss the intricacies of strike action, the limitations thereof and the consequences of strikes. The article will briefly highlight the following issues: The first part of the article explores the collective bargaining framework as well as the right to strike; the second part looks at what constitutes responsible unionism and the final part looks at the realities and problems that trade unions face.

\section{Collective Bargaining and Right to Strike}

\section{Collective Bargaining}

Collective bargaining has a long history, evidenced by developments in different countries, as well as by the importance it has played in granting workers a greater "voice" in organisations. Collective bargaining is largely an adversarial process, which involves negotiation between parties with conflicting interests "seeking to achieve mutually acceptable compromises". ${ }^{12}$ The right to engage in collective bargaining

5 Du Toit 'Democratising the employment relationship (a conceptual approach to labour law and its socio-economic implications)' 1993 Stell LR 325.

6 Ss 23(2), (3) \& 4 of the Constitution.

7 Ss $4 \& 5$ of the LRA as well as Chapter IV of the LRA.

8 S 22 of the Constitution.

9 S 23(5) of the Constitution.

10 Ss 23(1)(a), (2)(c) \& (5) of the Constitution.

11 Chapters II, III \& IV of the LRA, especially ss 64-68 (for strike provisions). The LRA also provides for protest action in s 77 .

12 Godfrey et al Collective Bargaining (2010) 1. 
"presupposes that workers are entitled to participate effectively in determining and defending their terms of employment" 13 For workers, it is primarily a means of maintaining "certain standards of distribution of work, of rewards and of stability of employment", ${ }^{14}$ whereas employers view it as a means of ensuring "industrial peace". ${ }^{15}$ In line with this discussion it is important to first look at the development of collective bargaining.

Collective bargaining is widely accepted as the primary means of determining employment terms and conditions in South Africa. Due to South Africa's particular history, collective bargaining has been "underlined by the legacy of deep adversarialism" between employers and organised labour. ${ }^{.6}$ It has been argued that various behaviours in the selection of collective representatives, the conduct of collective bargaining, and the enforcement of collective agreements are prescribed and proscribed by labour laws in that the greatest net benefit from collective bargaining can be obtained when a system is in place that promotes good faith bargaining and efficient enforcement of collective agreements. 17

The constitutional framework supports the provisions of the LRA. Section 23(5) of the Constitution provides that every trade union, employers' organisation and employer has the right to engage in collective bargaining. ${ }^{18}$ In SA National Defence Union $v$ Minister of Defence $\&$ Others ${ }^{19}$ O'Regan in an obiter dictum noted the following: ${ }^{20}$

13 Du Toit \& Ronnie 'The necessary evolution of strike law' 2012 Acta Juridica 198. In SAMWU \& Another $v$ SALGA \& Others 201031 ILJ 2178 (LC) the court said that " $[\mathrm{t}]$ he LRA introduced a voluntarist system of collective bargaining, a system in which neither this court (nor any other court or tribunal) is empowered to scrutinize bargain conduct or make pronouncements on the good faith or otherwise exhibited by any of the parties to collective bargaining' (par 16).

14 Du Toit "What is the Future of Collective Bargaining (and Labour Law) in South Africa' 2007 ILJ 1405 points out that the 'qualifier "primarily" is important: power built up in the bargaining arena enables trade unions also to engage with broader issues and exert political pressure'.

15 See Davies \& Freedland Kahn-Freund's: labour and the law (1983) 69 as well as Godfrey et al 1 and Du Toit 2007 ILJ supra n 14 at 1405.

16 Du Toit 'Collective Bargaining and Worker Participation' 2000 ILJ 1544.

17 Dau-Schmidt, Harris \& Lobel Labor and Employment Law (2009) 96.

18 It has been a widely controversial issue as to whether s 23 of the South African Constitution imposes a duty to bargain. See Cheadle, Davis \& Haysom South African Constitutional Law (2006) 18-25 where Cheadle develops three arguments against interpreting the right to engage in collective bargaining so as to include a positive right to bargain. S 27(4) of the Interim Constitution, 1993 was worded differently as it afforded works and employers the 'right to organise and bargain collectively'.

19 [2007] 9 BLLR 785 (CC) at par 55.

20 See also Van Niekerk \& Smit (eds) Law@work (2015) 366 regarding the SANDU case. The duty to bargain was deliberately excluded by the drafters of the LRA (Van Niekerk \& Smit (eds) 386). See in this regard The Explanatory Memorandum to the Draft Labour Relations Bill Prepared by the Ministerial Task Team 1995 ILJ 292. 
[I]t should be noted that were section 23(5) to establish a justiciable duty to bargain, enforceable by either employers or unions outside of a legislative framework to regulate that duty, courts may be drawn into a range of controversial industrial relations issues. These issues would include questions relating to the level at which bargaining should take place (i.e. the level of the workplace, at the level of an enterprise, or at industrial level); the level of union membership required to give rise to that duty; the topics of bargaining and the manner of bargaining. These are difficult issues, which have been regulated in different ways in the recent past in South Africa ...

Proponents of the right to organise have argued that collective bargaining not only allows employees the opportunity to gain a larger share of the fruits of their efforts, but also promotes equity in bargaining power between labour and management. ${ }^{21}$ The collective bargaining process therefore ensures that the interests of employees can be enforced by themselves or their trade union representatives, and also that an economic exchange between the collective workforce and the employer takes place. ${ }^{22}$

\section{The Right to Strike}

One of the purposes of the LRA (as indicated earlier) is to promote collective bargaining ${ }^{23}$ and to provide a framework within which employers, employers' organisations, trade unions and employees can bargain collectively to determine conditions of employment, formulate industrial policy and provide for other matters of mutual interest. ${ }^{24}$ It must be reiterated that the LRA sets out not only to promote "labour peace" but also "orderly collective bargaining" and "the effective resolution of labour disputes". 25 It is clear that the "right and concomitant duty to bargain collectively is enshrined in the LRA" 26 and is "integral to a system that sets out to civilise the workplace, to provide for a fair distribution between wage and profits, keep the economy vibrant and contribute to the wider democratic order". ${ }^{27}$

21 Dau-Schmidt, Harris \& Lobel 96.

22 Metcalf 'Workplace Governance and Performance' 1995 Employee Relations 9.

23 Chapter III of the LRA regulates collective bargaining in ss 11-63 of the Act.

24 Preamble and s 1 of the LRA. See for example Rand Tyre and Accessories (Pty) Ltd $v$ Industrial Council for the Motor Industry (Transvaal), Minister for Labour \& Minister for Justice 1941 TPD 108115 with regards to the meaning of matters of 'mutual interest'.

$25 \mathrm{~S} 1$ of the LRA (own emphasis). One of the aims of the LRA is providing simple procedures for the resolution of labour disputes through statutory conciliation, mediation and arbitration'. The CCMA was established for these purposes.

26 Davis \& Le Roux 'Changing the role of the corporation: A journey away from adversarialism' 2012 Acta Juridica 317.

27 Ibid; where they refer to Thompson 'Bargaining over business imperatives: The music of spheres after Fry's Metals' 2006 ILJ 785. 
Central to collective bargaining is the right to strike $e^{28}$ and the recourse to lock-out ${ }^{29}$ - respectively available to employees and employers. The processes of consultation and negotiation, as well as the recourse to lock out are options available to employers in their use of power in order to facilitate changes to the terms and conditions of employees. ${ }^{30}$ Strike action $^{31}$ is the economic weapon available to the employees and trade unions in collective bargaining, but is effective only in certain circumstances. It is argued that strikes grant workers a meaningful voice regarding what goes on in the workplace and thus grants them power to stop production and enables them to retain their dignity by showing the employer that they are "not just cogs in a machine". 32

The right to strike, freedom of association and organisation and the right to bargain collectively are all interrelated. The right to strike is, evidently, not only an essential component of the right to freedom of association ${ }^{33}$ but, is also "inextricably linked to a process of collective bargaining". 34 The right to strike enjoys a "high degree of protection" 35 in South Africa: The right to strike is: ${ }^{36}$

28 See, for example, South African Police Service $v$ Police and Prison's Civil Rights Union 2011 (6) SA 1 (CC) where the court confirmed that an important purpose of the LRA is to give effect to the right to strike and that the process of interpretation is important in order to give effect to the purpose 'so as to avoid impermissibly limiting the right to strike' (par 30).

29 S 213 of the LRA defines a lock-out as follows: "The exclusion by an employer of employees from the employer's workplace, for the purpose of compelling the employees to accept a demand in respect of any matter of mutual interest between employer and employee, whether or not the employer breaches those employees' contracts of employment in the course of or for the purpose of that exclusion'.

30 Davis \& Le Roux 2012 Acta Juridica 317.

31 A strike is defined by s 213 of the LRA as follows: "[T]he partial or complete concerted refusal to work or the retardation or obstruction of work, by persons who are or have been employed by the same employer or by different employers for the purpose of remedying a grievance or resolving a dispute over any matter of mutual interest between employer and employee, and every reference to "work" in this definition includes overtime work, whether it is voluntary or compulsory' (own emphasis). 'Concerted refusal to work' and the reference to persons clearly indicates that more than one person must be involved in the refusal to work. This was clearly indicated in Schoeman \& Another $v$ Samsung Electronics (Pty) Ltd [1997] 10 BLLR 1364 (LC) 1367 where the Labour Court held that an individual employee cannot strike and that a lock-out can also not be effected against a single employee. It is however possible for a single employer to lock-out employees. See also Du Toit $\mathbb{\&}$ Ronnie 2012 Acta Juridica 206 in this regard.

32 Chicktay 'Placing the Right to Strike within a Human Rights Framework' 2006 Obiter 348.

33 Manamela \& Budeli 'Employees' right to strike and violence in South Africa' 2013 CILSA 308.

34 Davis \& Le Roux 2012 Acta Juridica 319. See also NUMSA v Bader Bop (Pty) Ltd 20033 SA 513 (CC) par 13 in this regard.

35 Du Toit \& Ronnie 2012 Acta Juridica 204.

36 Van Niekerk \& Smit (eds) 415. 
[A]n essential means for the promotion of the social and economic interests of employees and trade unions, based ultimately on the proposition that trade unions should be free to organise their activities and formulate their programmes for the purposes of defending the interests of their members.

It is clear from the provisions of the Act that strike action (and the recourse to lock-out) should meet certain requirements for it to be protected. Although the right to strike is recognised by the Constitution in section 23(2), it is not absolute since it may be limited under certain circumstances. This limitation applies only to industrial action called by a trade union, in support of a demand related to the bargaining process or matters of mutual interest, being recognised as a "strike". The LRA also imposes a number of substantive and procedural limitations on the right to strike. ${ }^{37}$

The recourse to lock employees out of the workplace, is recognised only in the LRA, but it does not mean that the status or protection thereof is lesser or weaker than the right to strike. This sentiment was illustrated in the Constitutional Court's judgment in Ex parte Chairperson of the Constitutional Assembly: In re Certification of the Constitution of the Republic of South Africa 1996 in which the court held that: ${ }^{38}$

... the effect of including the right to strike does not diminish the right of employers to engage in collective bargaining, nor does it weaken their right to exercise economic power against workers. The right to bargain collectively is expressly recognised by the text ...

Yacoob ADCJ (in his majority judgment) in SATAWU $v$ Moloto, ${ }^{39}$ noted the importance of the right to strike as follows: ${ }^{40}$

... the right to strike, rooted in collective bargaining, is premised on the need to introduce greater balance in the relations between employers and employees, where employers have the greater social and economic power.

37 Strikes and lock-outs are dealt with in Chapter IV of the LRA. Secondary strikes are dealt with in s 66. Du Toit \& Ronnie 2012 Acta Juridica 205 point out that one of the implicit limitations which workers in standard employment may not experience as limitations at all is the fact that Constitution extends the right to strike to every 'worker' and that s 64(1) of the LRA confines it to 'employees'. They add that this limitation 'is significant to the extent that the term 'worker' is broader than the term 'employee', and changing patterns of production have resulted in work being performed by persons other than employees and thus there 'is a duty on the state to ensure, as far as possible, that not only employees but all workers are able to exercise this right effectively'.

381996 (4) SA 744 (CC) par 65.

392012 (6) SA 249 (CC) par 85.

40 The court went further in the SACAWU case par 85-86 regarding the minimal procedural pre-conditions set in s 64 of the LRA. 
It should be noted that workers are also afforded the right to take part in protest action, ${ }^{41}$ which "may take the same form as a normal strike" but which differs from a strike as its object is different - it deals with the socio-economic interests ${ }^{42}$ of workers. ${ }^{43}$

Legitimacy thus attaches to the right to strike when it is part of "a continuing collective bargaining process". 44 The right to strike is regarded as "a potential weapon that serves to maintain the equilibrium between labour and the concentrated power of capital". ${ }^{45}$ It is evident from the provisions of the LRA that labour peace and orderly collective bargaining ${ }^{46}$ should be promoted. ${ }^{47}$ Strike action should be peaceful: The strike should not only be orderly (in that it should be protected) but workers taking part in such a strike should refrain from misconduct. ${ }^{48}$

\section{Responsible Trade Unionism}

The role of trade unions is confined not only to the political arena but extends into the economic and social spheres. Labour, through trade unions, plays an important and active role in decision-making that "vitally concerns its interests" as important elements of social life. ${ }^{49}$ Trade unions have a duty not only to collaborate with other social institutions, which include representatives of management and capital, but they also have responsibilities when it comes to the production of wealth. ${ }^{50}$ Their duties are not limited to the distribution of wealth, but extend to the production thereof. Therefore, it is important for society as

41 S $77 \& 213$ of the LRA. S 213 of the LRA defines a protest action as the 'partial or complete concerted refusal to work, or the retardation or obstruction of work, for the purpose of promoting or defending the socioeconomic interest of workers, but not for the purpose referred to in the definition of a strike'.

42 See for example Government of the Western Cape Province v COSATU 1999 20 ILJ 151 (LC) where the court held that an all-embracing definition of socio-economic rights is not possible and that it should be viewed on a case by case basis and each on its own merits. The protest action against the Western Cape Education Department for the poor state of education fell within this meaning of socio-economic rights of workers.

43 Chicktay 'Defining the right to strike: A comparative analysis of International Labour Organization standards and South African law' 2012 Obiter 265. See also Gericke Revisiting the liability of trade unions and/or their members during strikes: Lessons to be learnt from case law' 2012 THRHR 570 where she points out that a 'political' strike and thus protest action would be best suited to affect the promotion of the socio-economic interests of workers.

44 Rycroft 'What can be done about strike-related violence?' 2 paper presented at Labour Law Research Network Inaugural Conference Pompeu Fabra University, Barcelona 13-15 June 2013.

45 Van Niekerk \& Smit (eds) 415.

46 Own emphasis.

47 S 1 of the LRA.

48 Rycroft supra $\mathrm{n} 43$ at 16

49 Lower Employee Participation in Governance: A legal and ethical analysis (2012) 151

50 Ibid. 
a whole, and not simply for corporations and their shareholders, that wealth creation takes place in a continuous and sustainable manner. Sustainable development and participatory democracy are inextricably connected and trade unions play a key role in the democratic process. ${ }^{51}$ The role of trade unions can be summarised as follows: ${ }^{52}$

Beyond their functions of defending and vindicating, unions have the duty of acting as representatives working for 'the proper arrangement of economic life' and of educating the social consciences of workers so that they will feel that they have an active role, according to their proper capacities and aptitudes, in the whole task of economic and social development and in the attainment of the universal common good.

Responsible unionism is relevant to the "interpretation of good faith bargaining by unions", 53 as well as to other issues such as governance and the exercising of the various rights and freedoms afforded to trade unions. It is clear that trade unions not only play an important role in the promotion of better working conditions for workers, but also contribute to shaping society at large.

It is important to note that the LRA provides not only for "a framework within which employees, trade unions, employers and employers' organisations can collectively bargain to determine wages, terms and conditions of employment and other matters of mutual interest", 54 but also aims to "promote orderly collective bargaining". 55 From a social justice perspective, trade unions are regarded as the primary vehicles through which social justice is achieved. ${ }^{56}$ This view is based upon Sir Kahn-Freund's conception of labour law, put forward in the 1950s and 1960s, as a means of counteracting the inequality in bargaining power between employers and employees. ${ }^{57}$ An equilibrium, according to Kahn-Freund, can be maintained and best achieved through voluntary collective bargaining in which the law plays (a secondary role) as "it regulates, supports and constrains the power of management and organised labour". ${ }^{58}$ The interests of the bargaining parties and their respective power drive not only the bargaining process but also the outcomes of the process. If a more contemporary social justice perspective is applied, it might not only "acknowledge collective bargaining as an important means to define and enforce protection for workers", but also "recognise rights as a complementary and perhaps more significant medium to promote social justice in the workplace". 59

51 Kester Trade Unions and Workplace Democracy in Africa (2007) 3.

52 Lower 151 where he quotes from The Compendium of the Social Doctrine of the Church.

53 Floyd 'Fair work laws: Good faith bargaining, union right to entry and the legal notion of "responsible unionism" 2009 ABLR 265.

$54 \mathrm{~S} 1$ (c)(i) of the LRA.

55 S $1($ d) (i) of the LRA.

56 Van Niekerk \& Smit (eds) 8.

57 Ibid.

58 See Davies \& Freedland 15 as well as Van Niekerk \& Smit (eds) 9.

59 Van Niekerk \& Smit (eds) 10. 
Trade unions are essential in the promotion and protection of the various rights of workers, but they should also ensure, in the promotion of worker interests, that they are sustainable. Unions sometimes face a dilemma: On the one hand they want more benefits through collective bargaining, but on the other, more "collective bargaining benefits" can increase the costs of labour and production which makes the firm less profitable and results, possibly, in reducing the number of workers. ${ }^{60}$ Some trade unions are concerned only with the improvement in the benefits of their members and demand higher wages "at the expense of employment levels", thereby overlooking the effect of their actions on other workers and on society. ${ }^{61}$ Other unions look for alternative outcomes such as the payment of "market wages" and look for ways to increase productivity that will result in a win-win situation. ${ }^{62}$

There is a situation in which pressure may be exerted by stakeholders, such as trade unions, which have institutional interests that can differ from the interests of their members (let alone those of employers), and other stakeholders outside the enterprise (such as consumers or environmental groups). ${ }^{63}$ Employers and employees may also be exposed to market and political pressures over which they have little or no control.

It is argued that trade unions should demonstrate a form of social responsibility. Union social responsibility can be defined as "the responsibility of a union to look after the interest of the wider economy beyond the interest of the union itself". ${ }^{64}$ However, it does not entail that trade unions should not seek to improve the terms and conditions of employment of their members. Rather, it is a question of whether the union looks after its members' interests now as well as later. It is a question which is especially relevant in times when industries, or the country as a whole, are in a distressed situation and job losses are evident, or the economy is in an ever greater downward spiral. It is not argued that trade unions should abandon negotiating with employers, but rather they should, for example, find an alternative to strikes in such a situation. It is commonplace that trade unions want to improve the employment conditions of their members: ${ }^{65}$ It is proposed that trade unions should "aim to improve the life of workers in a sustainable manner". 66

60 Chew \& Soon-Beng 'Union Responsibility: A necessary Public Good in a Globalized World' 2010 The International Journal of Comparative Labour Law and Industrial Relations 435.

61 Idem 436.

62 Ibid.

63 Du Toit 'Industrial democracy in South Africa's transition' 1997 Law. Democracy \& Development 43.

64 Chew \& Soon-Beng 2010 The International Journal of Comparative Labour Law and Industrial Relations 436.

65 Idem 438.

66 Ibid (own emphasis). 
The author, in order to determine what both sustainable and responsible trade unionism entails, proposes that it would be valuable to explore corporate governance and corporate social responsibility issues by way of an analogy. Corporate governance and social responsibility programmes play a significant role in the establishment and enforcement of basic labour rights, "especially in host countries that have little in the way of labour market regulation, or where to attract investment or for want of resources, minimum labour standards are not enforced". 67 The developments in the realm of corporate governance and social responsibility may serve to promote collective bargaining (to the extent that basic labour rights include the rights to organise and to bargain collectively), especially in environments in which the legislative environment remains hostile. ${ }^{68}$

It can be said that labour law originated by focusing on employment relations in order to regulate the conditions of tangible labour and to extend protection to workers' physical bodies; it then evolved to protect "employment" and to organise workers collectively within the enterprise (which is the economic locus of decision-making) to the point where workers' interests are taken into account, as well as their level of input in decision-making. ${ }^{69}$

Companies, for example, should offer an opportunity to align their expectations, ideas and opinions with those of other stakeholders on certain issues. ${ }^{70}$ The same can be said about trade unions. In the same way that companies should consider the legitimate interests of employees (as pointed out in the King Report on Corporate Governance for South Africa in 2009 (King III)), trade unions, as stakeholders, should consider the "legitimate interests" of their members at the negotiating table. An important responsibility resting on the shoulders of trade unions is that they should ensure that existing employees are gainfully employed. ${ }^{71}$

Sustainable development is significant here. An underlying philosophy of King III is that companies should be regarded as good corporate citizens in that they should subscribe to the sustainability considerations

67 Van Niekerk \& Smit (eds) 10.

68 Ibid.

69 Morin 'Labour law and new forms of corporate organization' 2005 International Labour Law Review 511.

70 King Report on Corporate Governance for South Africa in 2002 (Institute of Directors King Report II) 110-111.

71 Le Roux 'The purpose of labour law: Can it turn green?' in Malherbe \& Sloth-Nielsen (eds) Labour Law into the Future: Essays in honour of D'Arcy du Toit (2012) 240. 
that are rooted in the Constitution. ${ }^{72}$ Sustainability ${ }^{73}$ encompasses an inclusivity of stakeholders (which is essential in order to achieve sustainability), innovation, ${ }^{74}$ fairness and collaboration, ${ }^{75}$ as well as social transformation and redress. ${ }^{76}$ The manner in which a corporation treats its employees is also important. The principle of fairness is central for representative trade unions to ensure that employers treat the workers in a fair manner. Fairness is a key principle in addressing the issue of social injustice. ${ }^{77}$ Social injustice is unsustainable and is counterproductive. ${ }^{78}$ Fairness, thus, plays an important role in that society is not exclusively concerned with the maximisation of aggregate wealth but also with the equality of its distribution. ${ }^{79}$

Economic justice is, mostly, ignored in mainstream corporate law: When "people use bargained-for exchange to distribute goods, the weaker bargainer will be less able to extract concessions from the other". ${ }^{80}$ Labour, through trade unions, makes it possible for workers to have a form of economic justice. It is clear that even if the less-well-off party is marginally better off, the more powerful party to the contract will tend to be much better off: Unless there is "some explicit constraint on the ability of corporations to pass along the lion's share or profit to shareholders, the nation's inequality will worsen over time". 81 It is important for trade unions to take note not only of labour law when they bargain on behalf of workers, but also of certain corporate laws which extend certain rights to workers.

72 Sustainability of a company means "conducting operations in a manner that meets existing needs without compromising the ability of future generations to meet their needs. It means having regard to the impact that the business operations have on the economic life of the community in which it operates. Sustainability includes environmental, social and governance issues' (King Report on Corporate Governance for South Africa in 2009 (Institute of Directors King Report III) 60 (available from www.iod.com)

73 Institute of Directors King Report III 13.

74 Innovation will include new ways in which companies are doing things and will include for example profitable responses to sustainability (Institute of Directors King Report III 13).

75 Collaboration, for example, should not amount to 'anti-competitiveness' (Institute of Directors King Report III 13).

76 Social transformation and redress from 'apartheid' are important and should be integrated within the broader transition to sustainability because by integrating sustainability and social transformation 'in a strategic and coherent manner will give rise to greater opportunities, efficiencies, and benefits, for both the company and society' (Institute of Directors King Report III 13).

77 Institute of Directors King Report III 13.

78 Ibid.

79 Greenfield 'New principles for corporate law' 2005 Hastings Business Law Journal 109-110

80 Idem 111.

81 Ibid (own emphasis). 
Corporate law is well-suited and is an efficient means to promote fairness and to redistribute wealth and income, more so than other areas of regulation. ${ }^{82}$ A stakeholder-oriented corporate law "would work at the initial distribution of the corporate surplus and would benefit stakeholders up and down the economic hierarchy". ${ }^{83}$ If fairness is taken as seriously as a value, a corporate law framework, that does not promote fairness, cannot be blindly accepted. ${ }^{84}$ Corporate governance should focus on procedural fairness (rather than trying to reach agreement ex ante about substantive fairness): Its crucial objective is "to create methods of decision-making" that offer procedural fairness among the various stakeholders. ${ }^{85}$ In order to make it a real possibility that a corporation serves its stakeholders by creating wealth in a sustainable manner and shares the wealth in an equitable way, the management (and trade unions) need to be subject to different constraints. Good corporate governance, of which the advancement of sustainability is a fundamental component, has the potential not only to benefit the owners of the corporation but also those whom they employ. ${ }^{86}$ Trade unions, like management, should consider sustainability issues when they negotiate.

It can, at a basic level, be argued that employees would like corporations (as employers) to fulfil their basic needs, such as the payment of a fair wage, the provision of safe working conditions, job security, future career opportunities, et cetera. ${ }^{87}$ A decent work agenda should be promoted: Four core values, namely, the opportunity to work, the right to freedom of association, social protection, and "voice" are important. ${ }^{88}$ In this regard it is important to mention the International Labour Organisation's (ILO) thinking on the relationship between decent work and sustainability: ${ }^{89}$

The world needs more and better jobs, especially in societies suffering from widespread poverty, and these jobs must have the quality of sustainability. Decent work for sustainable development means that in social terms, such jobs must be open to all equally and the related rewards have to equitable. Inequality and discrimination provoke frustration and anger, and they are a recipe for social dislocation and political instability. Extending opportunities for decent work to more people is a crucial element in making globalization

82 Ibid.

83 Idem 112

84 Ibid.

85 Idem 113 (own emphasis).

86 Le Roux 'The purpose of labour law: Can it turn green?' in Malherbe \& Sloth-Nielsen (eds) supra $\mathrm{n} 68$ at 242.

87 Ibid

88 The concept decent work is based on the understanding that work is not only a source of income but more importantly a source of personal dignity, family stability, peace in community, and economic growth that expands opportunities for productive jobs and employment' (ILO 2010 www.ilo.org). See also in this regard Cohen \& Moodley "Achieving "decent work" in South Africa’ 2012 PER 320-569.

89 ILO 'Toolkit for Mainstreaming Employment and Decent Work' (2008) available from http://www.ilo.org 
more inclusive and fair. In economic terms, jobs have to be productive and able to compete in a competitive market. And environmentally, they must involve the use of natural resources in ways that conserve the planet for future generations, while being safe for working women and men and for the community.

Le Roux (in an exploratory paper) asks the question: "What does this [sustainability] imply for unions (and also employers), assuming that they do adopt the concept?" 90 Le Roux examines the possibility of trade unions adopting the concept of sustainability and how sustainable employment can be achieved. She points out that trade unions "will have to be mindful of the environment in their day-to-day operations, but sustainability ought to become the basis of their decision-making and, more importantly, the basis on which they bargain". ${ }^{91}$ Le Roux stresses the importance of sustainability as well as the achievement of sustainable employment as follows: ${ }^{92}$

While the best and immediate financial interests of their members will probably remain at the top of the bargaining agenda for unions, the proposed approach will require all stakeholders to consider not only how the wage bargain can feed into sustainability, but also how the bargaining process can add value to all five capitals [financial, human, social, environmental and manufactured] ... This may mean including sustainability issues (in the deep green sense), but more specifically sustainable employment, on the bargaining agenda. The details of sustainable employment will have to be developed over time, but examples include employer subsidies for the use of public transport as an incentive for car owners to use public transport, incentives for other energy-saving techniques by employees (instead of a higher percentage remuneration increase), work/life cycle incentives, and avoiding demands (for example, remuneration increases) which are simply not sustainable in particular economic climates and that will inevitably, if agreed to result in retrenchments and possibly encourage employers to mechanise where this was not necessarily planned. Sustainable employment may also mean developing social networks which advance social capital without necessarily advancing the wage bargain, such as training and education programmes for employees and even their families. Such an approach may also mean, if the transience of employment is indeed as intrinsic as suggested above, that it may be necessary to shift from employment security to employability as an underlying objective of employment (for example, re-skilling provided for by employers and employer assistance with post-employment schemes, such as the establishment of a co-operative that continues to provide a service to the employer). The important point is that sustainable employment will require all parties concerned to harness sustainability levels, including 'the self', 'the partnership' (employee/employer relationship) and 'the environment', and to abandon short-term goals for long-term benefits.

90 Le Roux 'The purpose of labour law: Can it turn green?' in Malherbe \& Sloth-Nielsen (eds) supra $\mathrm{n} 68$ at 242.

91 Ibid.

92 Idem 242-243. 
Le Roux (in a later article) ${ }^{93}$ acknowledges that the "decent work" agenda of the ILO was omitted and asks the question: "Does the fact that work is decent imply that it is also sustainable?" 94 She finds that there is a close interface between decent work and sustainable work, but that they are "probably not always the same thing": Decent work is "key to sustainable work, but in order to be sustainable, work should, in addition to being decent, also have an element of longevity or durability". 95 Sustainable work, it appears, at a micro level (while not guaranteeing the regularity of income associated with waged employment) may "hold the prospect of an 'ongoing earnings floor', personal growth, and empowerment”. 96

In view of the above, it is argued that trade unions that seek to improve the life of workers in a sustainable manner should be "macro-focused". 97 The aim of such "macro-focused" trade unions would be "to set wages at levels that would maximise employment, which is based on the competitiveness of the firms". 98 Such trade unions will also work closely with firms and government in order to achieve such competitiveness. ${ }^{99}$

A problem faced by macro-trade unions is the issue of free riders. The problem of free riders is addressed in South Africa by the so-called "closed-shop agreements" and "agency-shop agreements", in which either all employees, that work for an employer, are members of a majority representative trade union or non-members are forced to pay union membership fees. ${ }^{100}$ This practice addresses the issue of the survival of trade unions and enables a trade union to promote the interests of workers in a responsible manner.

It is thus argued, with regard to responsible unionism, that elements of responsible corporate citizenship should be applied to trade unions in evaluating whether or not they act in a responsible manner. Trade unions are equipped with huge amounts of social, economic and political power and need to be responsible when negotiating with employers, and other important role players and social partners, about the livelihoods of the most vulnerable workers. They are entrusted with a huge responsibility to care about the terms and conditions of employment but also to bargain from a sustainability perspective.

From the meaning attributed to corporate citizenship in King III, it is evident that responsible corporate citizenship implies "an ethical relationship between the company and the society in which it operates"

93 Le Roux 'A Social Economy and Sustainability: Is there Potential for an Interface?' 2013 Obiter 512-513.

94 Idem 519

95 Ibid.

96 Ibid

97 Chew \& Soon-Beng 2010 The International Journal of Comparative Labour 98 Ibid.

99 Ibid

100 Ss $25 \& 26$ of the LRA. 
and, as responsible corporate citizens of the societies in which they do business, "companies have, apart from rights, also legal and moral obligations in respect of their economic, social and natural environments". ${ }^{101}$ As a responsible corporate citizen, the company should protect, enhance and invest in the wellbeing of the economy, society and the natural environment. ${ }^{102}$ It is proposed that a responsible trade union should demonstrate the same traits if they, too, are to be responsible citizens. When bargaining or negotiating, they should take into account their various freedoms and rights, while also protecting, enhancing and investing in the wellbeing of the economy, society and the natural environment. It is important that trade unions take note of both their legal and moral obligations.

\section{Realities and Problems Faced by Trade Unions}

\section{Recourse to Lock-out and Replacement Labour}

In a strike, employers may resort to negotiation with employees or to a lock-out. ${ }^{103}$ Employers can utilise replacement labour as a bargaining tool. Section 76(1)(b) of the LRA provides that an employer can make use of replacement labour only when the lock-out is in response to a strike. Strike action can lose its edge in a depressed economy where jobs are scarce and there is a large pool of unemployed people so that employers can make use of replacement labour or scab labour when employees strike. However, an employer is prohibited from taking into employment any person to continue or maintain production during a protected strike if the whole or part of the employer's services has been designated a maintenance service, ${ }^{104}$ or to perform the work of any employee who is locked out, unless the lock-out is in response to a strike. ${ }^{105}$ This recourse is only available to the employer when the lock-out is in response to a strike. 106

\section{Beyond the Scope of Collective Bargaining}

A particular problematic instance relates to essential services and, in general, collective bargaining in the public sector. If the right to strike is limited (as is the case in essential services), employee participation arguably becomes even more important. ${ }^{107}$ In South Africa the number of unprotected strikes in the public sector, including in essential sectors such as health care and electricity services, indicates that neither the

101 Institute of Directors King Report III 117.

102 Ibid

103 Qotoyi \& Van der Walt 'Dismissals within the Context of Collective Bargaining’ 2009 Obiter 67.

104 S 76(1)(a) of the LRA.

105 S 76(1)(b) of the LRA.

106 S 76(2) of the LRA.

107 Essential, minimum and maintenance services are regulated in ss 70-75 of the LRA. 
collective bargaining model nor the dispute resolution system works effectively in these instances. Since 2007, collective bargaining in South Africa has become increasingly adversarial: " $[\mathrm{A}]$ decline in negotiating capacity, the re-emergence of non-workplace issues negotiations, and the rise of general mistrust between the parties" 108 are key factors contributing to the situation. ${ }^{109}$ Demands for the inclusion of social benefits, like medical aid schemes and the payment of transport and housing allowances, are on the increase. ${ }^{110}$ Workers seek not only equality in the workplace but also social justice (in the wide sense falling outside the ambit of collective bargaining) in order to satisfy socioeconomic conditions and seek the adequate delivery of social services. ${ }^{111}$

The absence of a mutually acceptable benchmark to target wage increases, is regarded as a contributing factor furthering the difficulty in resolving wage disputes. 112

\section{Long Term Collective Agreements}

In order to contribute to a stable bargaining climate, the trend is to negotiate multi-year (often up to three year) collective agreements. ${ }^{113}$ These have become more prevalent in many sectors. ${ }^{1}{ }^{4}$ Long termagreements are preferred by employers most notably in the steel and engineering, mining and automobile sectors to "ensure labour stability in the short/medium term". 115 Rivalry within and between trade unions affect dispute resolution in many sectors: "[T] rade union leaders facing a challenge to their position may be pressured into being less conciliatory in negotiations to ward off any criticism that they are insufficiently militant". 116 Traditional collective bargaining in which "deep-seated antagonism rather than any form of partnership or dialogue operates to solve the dispute" results in the parties going back and forth with high demands and low counter-offers with the negotiations resembling no more than a series of "perfunctory motions". 117 After a period of back and forth, the parties "incrementally remove non-wage related issues from the table", but it becomes increasingly difficult to bridge the gap in their positions; especially in relation to monetary demands. ${ }^{118}$ The

108 National Planning Commission (2012) par 34.

109 Benjamin 'Beyond Dispute Resolution: The Evolving Role of the Commission for Conciliation, Mediation \& Arbitration’ 2014 ILJ 3.

110 Idem 4.

111 Kahn 2012 A Chance to Reassess our System of Industrial Relations' http:// www.ccma.org.za/News.asp?L1 = 37 .

112 Benjamin 2014 ILJ 4.

113 Ibid

114 Ibid

115 Ibid.

116 Ibid.

117 Davis \& Le Roux 2012 Acta Juridica 319-320.

118 Idem 320 
parties resort to power-play to put pressure on each other: In the hand of trade unions the end result is, invariably, full-blown strike action. ${ }^{119}$

\section{Violent and Lengthy Strike Action}

Strike action sometimes becomes violent. Benjamin points out that in recent years industrial action "has been characterized by violent and destructive behaviour, as well as 'an observable contempt of the LRA and court orders'". ${ }^{120}$ The use of collective violence, aimed at the employer, non-striking workers or the general public "to strengthen a bargaining position relative to the employer", has been normalised to such an extent that it has been established as a tradition. ${ }^{121}$ It is submitted that a violent strike is not "functional to collective bargaining as it is not conducive to bargaining in good faith". ${ }^{22}$ It is clear that the right to strike does not offer striking employees a licence to engage in criminal and unruly conduct and violence during a strike should be regarded as "an abuse of the right to strike". ${ }^{123}$ Violent strikes are counterproductive of worker interests "in that workers do not have the resources to sustain their strikes for any protracted period of time'. ${ }^{124}$ Further, the strike "costs employers large amounts in damage to property, the expense of hiring private security firms, and the costs involved in litigation". ${ }^{125}$

A possible solution to the problem of lengthy strikes, and/or violent strikes, lies in a call to reintroduce strike ballots, evident in the initial amendment to the LRA in $2012 .^{126}$ With strikes under the spotlight, it is necessary to consider whether balloting should be made compulsory or whether compulsory arbitration should be implemented (when strikes are too damaging), as well as what sanctions "can be meted out for the strike violence that now seems to be regarded as de rigueur". ${ }^{127}$ These sanctions can include an award for damages based on violent or unlawful conduct, as well as withdrawing or cancelling the recognition of a trade union as a bargaining agent, and the consequential loss of statutory privileges, in cases where trade unions fail to take reasonable steps to control their members.

The amendment to section 64 of the LRA and the reintroduction of a ballot, before a protected strike or lock-out may commence, has not been included in the final version of Labour Relations Amendment Act 6 of

119 Ibid.

120 Benjamin 2014 ILJ 10.

121 Ibid.

122 Manamela \& Budeli 2013 CILSA 323.

123 Ibid. See also Transport \& General Workers Union of Southern Africa v Ullman Bothers (Pty) Ltd 1989 ILJ 1154 (IC); Food \& Allied Workers Union v National Co-operative Dairies Ltd (2) 1989 ILJ 490(IC); National Union of Metalworkers of SA $v$ GM Vincent Metal Sections (Pty) Ltd 1993 ILJ 1318 (IC).

124 Manamela \& Budeli 2013 CILSA 323.

125 Ibid.

126 Labour Relations Amendment Bill, 2012.

127 Brassey 'Labour law after Marikana: Is institutionalized collective bargaining in SA wilting? If so, should we be glad or sad?' 2013 ILJ 834. 
$2014 .^{128}$ The introduction of strike balloting was intended to prevent industrial action if it enjoys only minority support due to the fact that violence or intimidation are more likely to occur under these circumstances. The change was proposed in response to the high levels of unprotected strike action as well as the unlawful acts of intimidation and violence that accompanied the strikes in recent years in South Africa.

Before calling for a strike or lock-out, a trade union or employers' organisation would have had to conduct a ballot of its members entitled to participate in the industrial action. ${ }^{129}$ As a consequence, the strike or lock-out will be protected only if a majority of those who vote in the ballot vote in favour of industrial action. ${ }^{130}$ The Labour Relations Act 28 of 1956 contained balloting requirements but these were not re-enacted in the LRA. ${ }^{131}$ A principle reason for the omission was that the balloting requirements had given rise to "technical disputes over compliance and there was extensive litigation over this issue". ${ }^{32}$ Such issues can be dealt with by providing a certificate of compliance issued by the Commission for Conciliation, Mediation and Arbitration ("CCMA"), a bargaining council or an accredited private agency which serves as proof that a ballot has been staged in compliance with the statutory requirements. Currently, legislation does not require trade unions to conduct strike ballots before notice of protected strike action is given. Benjamin points out that many unions "do retain balloting requirements in their constitutions but a failure to comply with these is not a basis for interdicting strike action". 133 Section $67(7)$ of the LRA provides as follows in this regard:

The failure by a registered trade union or a registered employers' organisation to comply with a provision in its constitution requiring it to conduct a ballot of those of its members in respect of whom it intends to call a strike or lock-out may not give rise to, or constitute a ground for, any litigation that will affect the legality of, and the protection conferred by this section on, the strike or lock-out (own emphasis).

Balloting requirements were removed from legislation in 1995 owing to concern that they had provided "fertile soil for employers to interdict strikes and to justify dismissal of strikers in strikes that are technically irregular but otherwise functional to collective bargaining". ${ }^{134}$ Strike balloting did not make it into the final version of the Labour Relations Amendment Act 6 of 2014.

It appears the legislature was trying to address the problem of the rise in unprotected strikes (note the various versions of the proposed LRA

128 The Labour Relations Amendment Act came into effect on 2015-01-01.

129 Memorandum of Objects of the Labour Relations Amendment Bill, 2012.

130 Ibid.

131 Ibid.

132 Ibid.

133 Benjamin 2014 ILJ 11.

134 Von Holdt 'Institutionalisation, strike violence and local moral orders' 2010 Transformation 135. See also Benjamin 2014 ILJ 11. 
amendments). However, the problem lies deeper: Workers seem to use the right to strike as a tool to "fight injustices of inequality". 135

Section $65^{136}$ of the LRA (also provided for by the 2014 Labour Relations Amendment Act) was amended in order to eliminate the "anomalous distinction between disputes that can be adjudicated under the LRA in respect of which industrial action is currently restricted and those under other employment laws in respect of which there is no equivalent restriction". ${ }^{37}$ Ngcukaitobi argues that the consequences of the strike law amendments are profound and that two concerns emerge as a consequence of the fact that the Labour Court is granted the power to suspend a strike (or picket) in appropriate circumstances, and may also suspend a lock-out or suspend an employer from engaging in replacement labour during a strike or lock-out. ${ }^{138}$ The first concern is "whether [the amendment] will meet their stated objects of reducing the incidence of strike violence" and the second is "whether they are sufficiently tailor-made to address the true underlying socio-economic realities that lie behind strike violence". ${ }^{139}$ It seems that neither of these concerns will be addressed. ${ }^{140}$ At the stage when the balloting requirement was still included it was argued, even if the Bill passed into law, that it does not guarantee an end to unprotected violent strikes: All the proposed ballot requirement does is add additional administrative hurdles to the attainment of protected strike action. ${ }^{141}$ The ballot requirement is viewed as a limitation on the power of trade unions "and generally, an encumbrance to workers' constitutionally entrenched right to strike", as well as prejudicing trade union attempts to exercise their right to strike. ${ }^{142}$

\section{Liability of Trade Unions}

Trade unions have to deal with the reality of liability. Bad faith negotiations, union rivalry, disorderly and violent conduct during strikes

135 Ngcukaitobi 'Strike law, structural violence and inequality in the platinum hills of Marikana' 2013 ILJ 843.

136 S 7 of the 2014 Labour Relations Amendment Act amends s 65 of the principal Act as follows -

(a) by the substitution in subsection (1) for paragraph (c) of the following paragraph:

(c) the issue in dispute is one that a party has the right to refer to arbitration or to the Labour Court in terms of this Act or any other employment law and

(b) by the substitution in subsection (3) for paragraph (b) of the following paragraph:

(b) any determination made in terms of [the Wage Act] Chapter Eight of the Basic Conditions of Employment Act and that regulates the issue in dispute, during the first year of that determination.

137 Memorandum of Objects of the Labour Relations Amendment Bill, 2012.

138 Ibid

139 Ngcukaitobi 2013 ILJ 845.

140 Ibid.

141 Idem 849-850

142 Idem 845; see idem 851 for more detail regarding concerns with balloting. 
as well as the promotion of, and participation in, wildcat and unprotected strikes are against the spirit of the LRA which aims to promote orderly collective bargaining and labour peace. Rycroft points out that strike action can take two forms: ${ }^{143}$ First, a "conventional, non-violent strike action which is preceded by good faith negotiation" and second, a "violent strike action which is preceded by bad faith negotiation". Trade unions and their representatives (as indicated above) are responsible for how they conduct themselves during the collective bargaining process and should be responsible in the manner in which they promote the interests of their members and should take responsibility for their members during strike action. A more proactive measure, rather than the reactive and punitive mechanisms that are being utilised, should be sought. ${ }^{144}$

With reference to the responsibilities and liabilities of trade unions, two recent cases are discussed below. The first case, that of SA Transport and Allied Workers Union $v$ Garvis (City of Cape Town as Intervening Party and Freedom of Expression Institute as amicus curiae), ${ }^{145}$ illustrates how the responsibilities of trade unions can be extended in cases where they and their members elect to gather and take part in a public strike. The Constitutional Court had to look at the validity of section 11(2) of the Regulation of Gatherings Act ${ }^{146}$ in order to determine whether the trade union would escape liability (under section 11(1)) for damage resulting from the actions of its members who vandalised and looted shops during their gathering. Per Mogoeng $\mathrm{CJ}$, the court, with reference to section $11(1)$ and (2), held as follows: ${ }^{14}$

The somewhat unusual defence created for an organization facing a claim for statutory liability appears to have been made deliberately tight. Gatherings, by their very nature, do not always lend themselves to easy management. They call for extraordinary measures to curb potential harm. The approach adopted by Parliament appears to be that, except in the limited circumstances defined, organizations must live with the consequences of their actions, with the result that harm triggered by their decision to organise a gathering would be placed at their doorsteps. This appears to be the broad objective sought to be achieved by Parliament through section 11. The common law position was well known when section 11 was enacted. The limitations of a delictual claim for gatherings-related damage in meeting the policy objective gave rise to the need to enact section 11 to make adequate provision for dealing with the gatherings-related challenges of our times.

Parliament sought to ameliorate the impact of imposing liability on an organizer by providing for a viable, yet onerous, defence under section 11 (2). The purpose was: (i) to provide for the statutory liability of organizations, so as to avoid the common law difficulties associated with proving the existence of a legal duty on the organization to avoid harm; (ii) to afford the organizer a

143 Rycroft supra n 43 at 16 .

144 IIbid.

1452012 ILJ 1593 (CC).

146 Act 205 of 1993.

147 SATAWU v Garvis parr 38-39. 
tighter defence, allowing it to rely on the absence of reasonable foreseeability and the taking of reasonable steps as a defence to the imposition of liability; and (iii) to place the onus on the defendant to prove this defence, instead of requiring the plaintiff to demonstrate the defendant's wrongdoing and fault.

The court added that an organisation would escape liability only if the act or omission that caused the damage "was not reasonably foreseeable", and if it took reasonable steps within its power to prevent that act or omission. ${ }^{148}$ An important issue is the fact that participation in assemblies and demonstrations should be unarmed and peaceful. In this context it is important to note the court's reasoning: Jafta J (Zondo AJ concurring) emphasised that in section 17 of the Constitution everyone "who is unarmed has the right to go out and assemble with others to demonstrate, picket and present petitions to others for any lawful purpose": Thus, a peaceful demonstration. ${ }^{149}$ Four rights emerge from a plain reading of section 17: The right to assemble freely, to hold a demonstration, to hold pickets, and to present petitions. ${ }^{150}$ The inner working of these rights can be summed up as follows: ${ }^{151}$

In democracies like ours, which give space to civil society and other groupings to express collective views common to their members, these rights are extremely important. It is through the exercise of each of these rights that civil society and other similar groups in our country are able to influence the political process, labour or business decisions and even matters of governance and service delivery. Freedom of assembly by its nature can only be exercised collectively and the strength to exert influence lies in the numbers of participants in the assembly. These rights lie at the heart of democracy.

The Constitutional Court upheld the Supreme Court of Appeal's judgment and SATAWU's appeal was dismissed. ${ }^{152}$

A second case (although it does not deal with industrial action) serves as a useful illustration establishing the responsibilities of trade unions. In Food \& Allied Workers Union $v$ Ngcobo $^{153}$ a claim for damages was instituted against FAWU for its failure to perform the mandate which it accepted to represent its members before the CCMA, and the Labour Court. From the outset the court, per Ponnan JA and Plasket AJA (Malan and Tshiqi JJA concurring) noted that the claim of the respondents is

148 Idem par 42

149 Idem parr 51-53. Rautenbach 'The liability of organisers for damage caused in the course of violent demonstrations as a limitation of the right to freedom of assembly' 2013 TSAR 160 addresses the following reality: 'We are, however, faced with the reality that section 17 protects only "peaceful and unarmed" assemblies, demonstrations and pickets, and the only way in which to minimise the effect of instinctive, 'definitional' limitation, is to interpret the 'peaceful and unarmed' broadly'.

150 SATAWU V Garvis par 120, as per Jafta J (Zondo AJ concurring).

151 Ibid.

152 The Court held that public interest 'trumps' the demand made by workers due to the fact that the public is entitled to be protected from 'the tyranny of the mob'.

1532013 ILJ 1383 (SCA). 
based not on delict, but on a breach of contract because of the alleged contract between the parties which imposed an obligation on FAWU and that it failed to perform in the manner contemplated by that contract. ${ }^{154}$ The court added that after FAWU accepted the mandate, the principal duty of FAWU was to carry it out and, therefore, they were in breach of that duty when they failed to timeously refer the dispute to the Labour Court. ${ }^{155}$ An order for twelve months compensation was made in favour of the respondents against FAWU.

\section{Concluding Remarks}

From the above it is evident that trade unions play an important role not only in the workplace, but also in society and in the economy. Socioeconomic issues cannot be separated from issues directly related to the workplace; strikes in recent months years are evidence of this. The adversarial nature of collective bargaining does not help the situation. Frustrations arising out of poor service delivery, infighting between members of trade unions (including COSATU) as well as union rivalry, add to the problem, as do unrest and violent industrial action. Good faith bargaining, orderly bargaining and labour peace should be at the heart of dispute resolution and negotiation: These goals underlie the purpose of this paper. SATAWU $v$ Garvis and FAWU v Ngcobo both illustrate the important role that trade unions play in the democratic processes, inside and outside of the workplace, and highlight the fact that trade unions have a responsibility towards workers and society at large - they are important agents not only when they represent workers but also in the promotion of stability in and outside the work environment. ${ }^{156}$

It is proposed that trade unions should act responsibly in engaging with other trade unions, role players and negotiating parties. As proposed in the article, issues, such as sustainability, accountability, and corporate citizenship, should be at the forefront of how trade unions negotiate: Negotiating long-term collective agreements for the future rather than short-term financial benefits. Job protection, beyond the risk of job losses or cuts, should be their concern. The employment relationship can never be an equal one: When trade unions negotiate or bargain they should bear in mind why they negotiate, on whose behalf they negotiate and whether their interests are in conflict with the interests of their members, society at large, as well as the economy. Although a novel idea, it is proposed that small changes in the manner in which negotiations are approached will, ultimately, have an impact on the end result. But it begs the question: Is responsible unionism a viable option in South African labour relations? In answering in the affirmative, is to suggest we have the tools. But how are these tools utilised?

154 FAWU v Ngcobo par 45.

155 Idem par 51 .

156 See also Gericke 2012 THRHR 584 regarding the important role trade unions play. 
Cooperation among the different social, economic and political partners is key. 